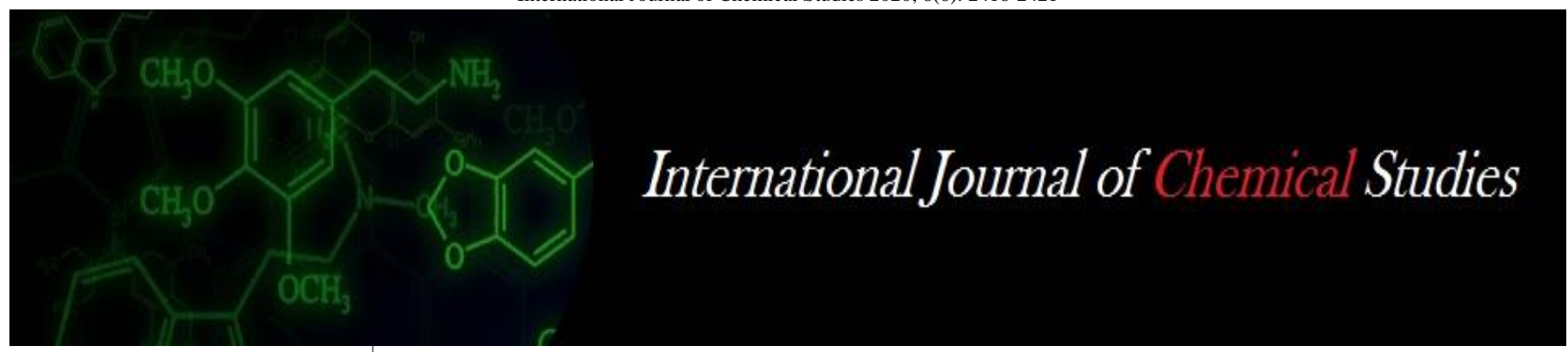

P-ISSN: 2349-8528

E-ISSN: 2321-4902

www.chemijournal.com

IJCS 2020; 8(6): 2416-2421

(C) 2020 IJCS

Received: 08-09-2020

Accepted: 17-10-2020

\section{Kiyam Heliken}

Department of Agroforestry,

College of Agriculture, Indira

Gandhi Krishi Viswavidyalaya,

Raipur, Chhattisgarh, India

Pratap Toppo

Department of Agroforestry,

College of Agriculture, Indira

Gandhi Krishi Viswavidyalaya,

Raipur, Chhattisgarh, India

\section{RK Prajapati}

Department of Agroforestry, College of Agriculture, Indira Gandhi Krishi Viswavidyalaya, Raipur, Chhattisgarh, India

PK Joshi

Department of Agroforestry, College of Agriculture, Indira Gandhi Krishi Viswavidyalaya,

Raipur, Chhattisgarh, India

\section{Lakhera}

Department of Agroforestry, College of Agriculture, Indira Gandhi Krishi Viswavidyalaya, Raipur, Chhattisgarh, India

\section{SS Porte}

Department of Agroforestry, College of Agriculture, Indira Gandhi Krishi Viswavidyalaya, Raipur, Chhattisgarh, India

Corresponding Author: Kiyam Heliken

Department of Agroforestry, College of Agriculture, Indira Gandhi Krishi Viswavidyalaya, Raipur, Chhattisgarh, India

\section{Effect of organic manures on growth and yield of Safedmusli (Chlorophytum borivilianum Sant. \& Fern.) Under Karanj (Pongamia pinnata L.) based agroforestry system}

\author{
Kiyam Heliken, Pratap Toppo, RK Prajapati, PK Joshi, ML Lakhera and \\ SS Porte
}

DOI: https://doi.org/10.22271/chemi.2020.v8.i6ai.11132

\begin{abstract}
The experiment was carried out on an important herbal and medicinal crop, safedmusli (Chlorophytum borivilianum Sant. \& Fern.) under karanj based agroforestry system at Indira Gandhi Krishi Vishwavidyalaya, Raipur. The experimental materials were planted in Randomized Block Design with eight treatments and three replications under $6 \mathrm{~m} \times 6 \mathrm{~m}$ spacingkaranj plantation. Statistically high significant results were obtained in number of leaves/plant, length of tuber, number of tubers/plant, tuber yield (kg/plot) and tuber yield (Q/ha). Significant readings were also recorded on soil chemical properties against different organic manure treatments. Vermicompost $(100 \%)$ performed outstanding for improvement of tuber length $(11.85 \mathrm{~cm})$, number of tubers $(8.57$ no.), number of leaves/plant $(27.89$, 90DAP), tuber yield $(4.37 \mathrm{~kg} / \mathrm{plot})$ and tuber yield $(33.62 \mathrm{Q} / \mathrm{ha})$.High performance of vermicompost could be due to very rich and diverse microbial populations present in vermicompost. The soil chemical properties on post harvest soils was also observed with higher concentrations of $\mathrm{N}(213.66 \mathrm{~kg} / \mathrm{ha})$ and $\mathrm{K}_{2} \mathrm{O}(465.12 \mathrm{~kg} / \mathrm{ha})$ in vermicompost $(100 \%)$ treated plot. This experiment also revealed that safedmusli can be successfully grown in karanj based agroforestry system with mutual benefit.
\end{abstract}

Keywords: Safed musli (Chlorophytum borivilianum Sant. \& Fern.), yield parameters, post harvest soil properties, karanj performance

\section{Introduction}

Chlorophytum borivilianum Sant. \& Fern. popularly known as safedmusli, belonging to family Liliaceae is a traditionally rare Indian herb considered as a 'white gold' or 'divyaaushad'. The centre of origin of the genus Chlorophytum is believed to be tropical and subtropical Africa and was introduced in India from South Africa (Khanam et al., 2013) ${ }^{[1]}$. It is widely distributed in India mainly in Southern Rajasthan, Western Madhya Pradesh, North Gujarat and few parts of Karnataka. Its dried roots are considered as wonder drug in Indian systems of medicine (Ayurveda, Unani and Siddha) due to its aphrodisiac and sex tonic properties. Because of great therapeutic importance, safedmusli roots are the major constituents of more than 100 Ayurvedic formulations (Oudhia, 2000) ${ }^{[2]}$. The National Medicinal Plants Board (NMPB), set up by the Government of India has ranked safedmusli as the 6th among the 28 selected priority medicinal plants for cultivation and export (Purohit and Prajapati, 2003; Gayathri and Uma, 2009). Despite its importance, the current annual demand of safedmusli roots in India is estimated to be 3500 tonnes as against the supply of 500-600 tonnes (Kothari and Singh, 2001) ${ }^{[3]}$. In indigenous Indian market, rate of dry musli is around Rs. 800 to 1,800 per $\mathrm{kg}$ in whereas in the international market, it is about Rs. 3,000 per kg (Khanam et al., 2013 ${ }^{[1]}$. Cultivation of safedmusli can be done in warm and humid areas that receive 50-150 $\mathrm{cm}$ annual precipitation for optimum plant growth and fleshy root development. Too high day temperature $\left(35^{\circ} \mathrm{C}\right.$ and above) does not favour plant growth. Multipurpose trees can be of many benefits to high value crops when used as intercrops.

Karanj (Pongamia pinnata L.) is a potential tree borne oil seed species (TBOS) belonging to Leguminosae family (Suvera et al., 2015) ${ }^{[4]}$ and has been used in many agroforestry systems. 
Apart from TBOS, it is also a nitrogen fixer, suitable for problematic soils and drought conditions (Duke, 1983) [5], suitable tree in agroforestry (Beniwal and Chauhan, 2011) [6] and a good botanical against phytopathogenic fungi (Kumari et al., 2013 and Dhingani et al., 2013) ${ }^{[7,8]}$. The tree is known for its multipurpose benefits and as a potential source of biodiesel (Naik et al., 2008).It grows abundantly along the coasts and riverbanks in Myanmar. The seeds are reported to contain on average about $28-34 \%$ oil with high percentage of polyunsaturated fatty acids (Sarma et al., 2005) [9]. Historically, Pongamia has been used as folk medicinal plant, particularly in Ayurveda and Siddha systems of Indian medicine (Meera et al., 2003) ${ }^{[10]}$. The study on the performance of different organic treatments on safedmusli is crucial for standardizing optimum treatment for the improvement of growth and yield of safedmusli and understanding the suitability of safedmusli under karanj based agroforestry system in Chhattisgarh.

\section{Materials and Methods}

The field experiments of the present investigation were carried out at Herbal Garden, Indira Gandhi Krishi Vishwavidyalaya, Raipur which lies at $21^{\circ} .76^{\prime} \mathrm{N}$ latitude and $81^{\circ} .36^{\prime}$ E longitude having an altitude of $295 \mathrm{~m}$ above mean sea level. The soil of experimental area was black clayey soil, which is locally known as Kanhar, fine texture, sticky nature, angular blocky structure, low to medium nitrogen, high potassium and low to medium phosphorus with low organic matter. The experimental materials were planted in Randomized Block Design with eight treatments and three replications under $6 \mathrm{~m} \times 6 \mathrm{~m}$ spacingkaranj (Pongamia pinnata L.) plantation. Raised beds of $20 \mathrm{~cm}$ high and $4 \mathrm{~m} \times 3.25 \mathrm{~m}$ size were made in such a way that in each plot, number of trees representation was equal. Each plot was treated by mixing the soil thoroughly with the organic manure before planting safedmusli as per treatments (T1: 100\% FYM @ 10 ton $\mathrm{ha}^{-1}, \mathrm{~T} 2: 100 \%$ Vermicompost @ 5 ton ha $\mathrm{ha}^{-1}, \mathrm{~T} 3: 100 \%$ Neem cake@4 ton ha ${ }^{-1}$, T4: 50\% FYM @ 5 ton ha-1 + 50\% Vermicompost @ 2.5 ton ha ${ }^{-1}$, T5: 50\% FYM @ 5 ton ha ${ }^{-1}+$ 50\% Neem Cake@ 2 ton ha ${ }^{-1}$, T6: 50\% Vermicompost @ 2.5 ton $\mathrm{ha}^{-1}+50 \%$ Neem cake@ 2 ton ha $\mathrm{ha}^{-1}$, T7: 50\% FYM @ 5 ton $\mathrm{ha}^{-1}+25 \%$ Vermicompost @ 1.25 ton $\mathrm{ha}^{-1}+25 \%$ Neem Cake@1 ton ha ${ }^{-1}$ while T8 was kept as control (no treatment). Tubers of approximately $5 \mathrm{gms}$ were used for planting in the last week of June, 2018 with a spacing of 40 $\mathrm{cm} \times 20 \mathrm{~cm}$.

Several growth parameters of safedmusli such as number of leaves (no.), number of root tubers per plant, length of root tubers $(\mathrm{cm})$, fresh root tuber yield $\left(\mathrm{kg} \mathrm{ha}^{-1}\right)$ and tuber yield (Q/ha). Moreover, karanj tree parameters such as height of tree $(\mathrm{m})$, number of branches/tree (no.) and DBH (diameter at breast height in $\mathrm{cm}$ ) were also recorded. Post harvest soil properties were determined as per standard methods. The analysis of variance for the studied traits was analyzed as per Panse and Sukhatme (1967) ${ }^{[11]}$ and statistical comparison was worked out based on student's paired ' $t$ ' test.

\section{Results and Discussion}

The treatments varied significantly for all the crop parameters and soil parameters under studied which is presented in Table 1. The mean squares due to treatments were highly significant for all the parameters indicating treatment differences for all the parameters studied. The coefficient of variation was below $10 \%$, for all characters confirming the reliability of the experiment and indicating less treatment by environment interactions except for number of leaves (no.) @ 60DAP, indicating moderate treatment by environment interaction. Similar significant treatments of organic manures in Safed musli crop were also recorded by Kothari and Singh (2003) ${ }^{[12]}$, Patel et al. (2008) ${ }^{[13]}$, Gaikwad et al. (2011a, 2011b) ${ }^{[14}$ ${ }^{15]}$, Chauhan et al. (2005) ${ }^{[23]}$ and Kulmi and Tyagi (2010) ${ }^{[24]}$.

Table 1: Analysis of variance for different parameters of Safed musli intercropped under Pongamia pinnata based agroforestry system.

\begin{tabular}{|c|c|c|c|c|c|c|c|}
\hline \multirow{3}{*}{$\begin{array}{c}\text { Source of } \\
\text { variation (d.f) }\end{array}$} & \multicolumn{6}{|c|}{ Mean sum of squares } & \multirow[b]{3}{*}{$\begin{array}{c}\text { Tuber yield } \\
\text { (Q/ha) }\end{array}$} \\
\hline & \multicolumn{6}{|c|}{ Yield parameters of Safed musli } & \\
\hline & $\begin{array}{c}\text { No. of leaves/ } \\
\text { plant @ 30DAP }\end{array}$ & \begin{tabular}{|c|} 
No. of leaves/ \\
plant @ 60DAP
\end{tabular} & $\begin{array}{c}\text { No. of leaves/ } \\
\text { plant @ 90DAP }\end{array}$ & $\begin{array}{l}\text { Length of } \\
\text { tuber }(\mathrm{cm})\end{array}$ & $\begin{array}{c}\text { No. of } \\
\text { tubers/plant }\end{array}$ & $\begin{array}{c}\text { Tuber yield } \\
\text { (kg/plot) }\end{array}$ & \\
\hline Replication (2) & 0.086 & 12.469 & 2.678 & 0.085 & 0.049 & 0.011 & 0.658 \\
\hline Treatment (7) & $7.444 * *$ & $20.694 * *$ & $45.655^{* *}$ & $14.102 * *$ & $7.144 * *$ & $0.651 * *$ & $38.61 * *$ \\
\hline Error (14) & 0.067 & 4.752 & 4.820 & 0.070 & 0.072 & 0.012 & 0.677 \\
\hline \multirow[t]{4}{*}{$\mathrm{CV}(\%)$} & 2.789 & 12.833 & 8.941 & 2.954 & 3.406 & 2.902 & 2.875 \\
\hline & \multicolumn{6}{|c|}{ Mean sum of squares } & \\
\hline & \multicolumn{6}{|c|}{ Soil nutrient parameters } & \\
\hline & \multicolumn{2}{|c|}{ Nitrogen $(\mathrm{kg} / \mathrm{ha})$} & \multicolumn{2}{|c|}{ Phosphorus (kg/ha) } & \multicolumn{2}{|c|}{ Potassium (kg/ha) } & \\
\hline Replication (2) & \multicolumn{2}{|c|}{23.593} & \multicolumn{2}{|c|}{0.193} & \multicolumn{2}{|c|}{16.408} & \\
\hline Treatment (7) & \multicolumn{2}{|c|}{$3,668.620^{* *}$} & \multicolumn{2}{|c|}{$76.293 * *$} & \multicolumn{2}{|c|}{$10,881.50^{* *}$} & \\
\hline Error (14) & \multicolumn{2}{|c|}{19.551} & \multicolumn{2}{|c|}{0.177} & \multicolumn{2}{|c|}{15.294} & \\
\hline $\mathrm{CV}(\%)$ & \multicolumn{2}{|c|}{2.788} & \multicolumn{2}{|c|}{2.929} & \multicolumn{2}{|c|}{1.072} & \\
\hline
\end{tabular}

The mean data pertaining to variation in number of leaves @30DAP, 60DAP and 90DAP against different treatments under karanj based agroforestry system is given in Table 2. The different organic manure treatments gave significant results at $(P<0.01)$. The maximum number of leaves per plant was recorded 11.21, 20.14 and 27.89 at 30, 60 and 90 DAP respectively under $\mathrm{T}_{2}$ followed by $\mathrm{T}_{4}$ i.e. $10.82,19.35$ and 27.44 at 30, 60 and 90 DAP respectively, whereas the minimum number of leaves per plant i.e.6.74, 13.21 and 17.62 was recorded 30, 60 and 90 DAP respectively, under $T_{8}$. The maximum increase in the number of leaves per plant was observed on application of $\mathrm{T}_{2}$ (Vermi-compost $100 \%$ ) with $58.29 \%$ increment followed by $55.73 \%$ in $\mathrm{T}_{4}(\mathrm{FYM}$ $50 \%+$ Vermi-compost $50 \%$ )and $53.97 \%$ in $\mathrm{T}_{7}$ (FYM $50 \%+$ Vermi-compost $25 \%+$ Neem cake $25 \%$ ) showed more or less similar role of both vermicompost and FYM(Table- \& Fig.). While $\mathrm{T}_{3}$ (Neem cake $100 \%$ ) on number of leaves per plant increase only by $10.56 \%$ possibly due to the toxic effect of neem cake which inhibits the formation of leaves. In rest of the cases, the formation of number of leaves per plant was increased by $37.46 \%$ to $51.19 \%$. 
Table 2: Effect of organic manures on number of leaves/plant of safedmusli intercropped under Pongamia pinnata based agroforestry system.

\begin{tabular}{|c|c|c|c|}
\hline \multirow{2}{*}{ Treatments } & \multicolumn{3}{|c|}{$\begin{array}{l}\text { Number of } \\
\text { leaves/plant }\end{array}$} \\
\hline & $\begin{array}{c}\text { 30 } \\
\text { DAP }\end{array}$ & \begin{tabular}{|c|}
60 \\
DAP
\end{tabular} & $\begin{array}{c}90 \\
\text { DAP }\end{array}$ \\
\hline $\mathrm{T}_{1}(\mathrm{FYM} 100 \%)$ & 8.23 & 15.23 & 24.22 \\
\hline $\mathrm{T}_{2}$ (Vermi-compost $100 \%$ ) & 11.21 & 20.14 & 27.89 \\
\hline $\mathrm{T}_{3}($ Neem cake $100 \%)$ & 7.85 & 13.76 & 19.48 \\
\hline $\mathrm{T}_{4}(\mathrm{FYM} 50 \%+$ Vermi-compost $50 \%)$ & 10.82 & 19.35 & 27.44 \\
\hline $\mathrm{T}_{5}(\mathrm{FYM} 50 \%+$ Neem cake $50 \%)$ & 10.55 & 19.01 & 26.64 \\
\hline $\mathrm{T}_{6}($ Vermi-compost $50 \%+$ Neem cake $50 \%)$ & 9.16 & 17.31 & 26.02 \\
\hline $\mathrm{T}_{7}(\mathrm{FYM} 50 \%+$ Vermi-compost $25 \%+$ Neem cake $25 \%$ ) & 9.46 & 17.88 & 27.13 \\
\hline $\mathrm{T}_{8}($ Control $)$ & 6.74 & 13.21 & 17.62 \\
\hline C.D $(P=0.05)$ & 0.456 & 3.854 & 3.882 \\
\hline S.Em \pm & 0.149 & 1.259 & 1.268 \\
\hline
\end{tabular}

The effects of organic manure on length of tuber $(\mathrm{cm})$ are given Table 3 . Length of tuber $(\mathrm{cm})$ showed statistically significant $(P<0.05)$ differences for organic manure treatments under Pongamia pinnata based agroforestry system. Maximum length of tubers was recorded $11.85 \mathrm{~cm}$ in $\mathrm{T}_{2}$ (Vermi-compost $100 \%$ ) followed by $11.32 \mathrm{~cm}$ in $\mathrm{T}_{4}$ (FYM $50 \%+$ Vermi-compost $50 \%$ ) and $11.08 \mathrm{~cm}$ in $\mathrm{T}_{7}$ (FYM $50 \%+$ Vermi-compost 25\%+Neem cake 25\%). While minimum was observed $6.32 \mathrm{~cm}$ in $\mathrm{T}_{8}$ (Control) i.e. no manuring. Role of vermicompost was found prominent for length of tuber $(\mathrm{cm})$ and it enhanced $87.5 \%$ higher in $\mathrm{T}_{2}$ (Vermi-compost $100 \%$ ) followed by $\mathrm{T}_{4}$ (FYM 50\%+Vermicompost $50 \%$ ) with $79.11 \%$ increased in length of tuber $(\mathrm{cm})$ and $75.31 \%$ increment in $\mathrm{T}_{7}(\mathrm{FYM} 50 \%+$ Vermi-compost $25 \%+$ Neem cake $25 \%$ ). Significantly higher fasiculated root length was observed with application of vermicompost @ 2 t/ha along with root treatment of Azotobactor as reported by Gaikwad et al. (2011a) ${ }^{[14]}$ in safedmusli and Emura and Hosoya (1979) [25] in carrot. Shravankumar and Soumana (2016) ${ }^{[26]}$ also reported maximum root length $(20.1 \mathrm{~cm})$ from a plot treated with vermicompost $(15 \mathrm{t} / \mathrm{ha})$ in Withania somnifera L.

Table 3: Effect of organic manures on length of tuber $(\mathrm{cm})$ of safedmusli intercropped under Pongamia pinnata based agroforestry system

\begin{tabular}{|c|c|}
\hline Treatments & $\begin{array}{c}\text { Length of } \\
\text { tuber }(\mathbf{c m})\end{array}$ \\
\hline $\mathrm{T}_{1}$ (FYM 100\%) & 7.94 \\
\hline $\mathrm{T}_{2}$ (Vermi-compost 100\%) & 11.85 \\
\hline $\mathrm{T}_{3}$ (Neem cake 100\%) & 6.63 \\
\hline $\mathrm{T}_{4}(\mathrm{FYM}$ 50\%+Vermi-compost 50\%) & 11.32 \\
\hline $\mathrm{T}_{5}(\mathrm{FYM} 50 \%+$ Neem cake 50\%) & 7.99 \\
\hline $\mathrm{T}_{6}($ Vermi-compost 50\% +Neem cake 50\%) & 8.63 \\
\hline $\mathrm{T}_{7}(\mathrm{FYM}$ 50\%+Vermi-compost 25\%+Neem cake 25\%) & 11.08 \\
\hline $\mathrm{T}_{8}($ Control) & 6.32 \\
\hline C.D $(P=0.05)$ & 1.219 \\
\hline S.Em \pm & 0.153 \\
\hline
\end{tabular}

Number of tubers/plant showed statistically significant $(\mathrm{P}<0.05)$ differences for organic manure treatments under Pongamia pinnata based agroforestry system (Table 4). Maximum number of tubers/plant was recorded 8.57 in $\mathrm{T}_{2}$ (Vermi-compost $100 \%$ ) followed by 8.13 in $\mathrm{T}_{1}$ (FYM 100\%) and 7.89 in $\mathrm{T}_{4}$ (FYM 50\%+Vermi-compost 50\%). While minimum was observed 5.25 in $\mathrm{T}_{8}$ (Control) i.e. no manuring. Role of vermicompost was found prominent again for number of tubers/plant and it enhanced $59.88 \%$ higher in $\mathrm{T}_{2}$ (Vermicompost $100 \%$ ) followed by $\mathrm{T}_{1}$ (FYM $100 \%$ ) with $51.68 \%$ increased in number of tubers/plant and $47.20 \%$ increment in $\mathrm{T}_{4}$ (FYM 50\%+Vermi-compost 50\%). The application of neem cake in $\mathrm{T}_{3}$ (Neem cake $100 \%$ ) showed minimum increase in number of tubers/plant i.e. only $12.13 \%$ increment possibly due to its toxic effects on crop as compared to other organic manure. Similarly, due to negative effect of neem cake in $\mathrm{T}_{5}(\mathrm{FYM} 50 \%+$ Neem cake $50 \%)$ and $\mathrm{T}_{6}($ Vermicompost $50 \%+$ Neem cake $50 \%$ ), only $28.54 \%$ and $30.78 \%$ were recorded respectively. In case of $\mathrm{T}_{7}$ (FYM 50\%+Vermicompost $25 \%+$ Neem cake $25 \%$ ), the number of tubers/plant was increased by $44.22 \%$ against control $\left(\mathrm{T}_{8}\right)$ i.e. zero manure application. Similar observations were also recorded by Gaikwad et al. (2011a) [14] where maximum numbers of fasiculated roots per plant of safedmusli were found in the application of vermicompost @ $2 \mathrm{t} / \mathrm{ha}$ along with treatment of Azotobactor which was at par with application of vermicompost @2t/ha alone and lower number of fasiculated roots per plant were recorded under the absolute control. These findings are in conformity with the observation of Alam et al. (2007) ${ }^{[27]}$ and Bong and Naher (2004) ${ }^{[28]}$.

Table 4: Effect of organic manures on number of tubers/plant of Safed musli intercropped under Pongamia pinnata based agroforestry system.

\begin{tabular}{|c|c|}
\hline Treatments & $\begin{array}{c}\text { Number of } \\
\text { tubers/plant }\end{array}$ \\
\hline $\mathrm{T}_{1}(\mathrm{FYM} \mathrm{100 \% )}$ & 8.13 \\
\hline $\mathrm{T}_{2}$ (Vermi-compost 100\%) & 8.57 \\
\hline $\mathrm{T}_{3}($ Neem cake 100\%) & 6.01 \\
\hline $\mathrm{T}_{4}(\mathrm{FYM}$ 50\%+Vermi-compost 50\%) & 7.89 \\
\hline $\mathrm{T}_{5}(\mathrm{FYM} 50 \%+$ Neem cake 50\%) & 6.89 \\
\hline $\mathrm{T}_{6}$ (Vermi-compost 50\% +Neem cake 50\%) & 7.01 \\
\hline $\mathrm{T}_{7}(\mathrm{FYM}$ 50\%+Vermi-compost 25\%+Neem cake 25\%) & 7.73 \\
\hline $\mathrm{T}_{8}($ Control) & 5.36 \\
\hline C.D $(P=0.05)$ & 0.476 \\
\hline S.Em \pm & 0.155 \\
\hline
\end{tabular}

Organic manure treatments showed significant differences on tuber yield (kg/plot) of safedmusli. The results on tuber yield (kg/plot) are depicted (Table 5). Tuber yield (kg/plot) was recorded maximum in $\mathrm{T}_{2}$ (Vermi-compost $100 \%$ ) i.e4.37 kg followed by $\mathrm{T}_{1}$ (FYM 100\%) and $\mathrm{T}_{4}$ (FYM 50\%+Vermicompost 50\%) which recorded $4.23 \mathrm{~kg}$ and $4.03 \mathrm{~kg}$ respectively while the minimum tuber yield (kg/plot) was $3.11 \mathrm{~kg}$ in $\mathrm{T}_{8}$ i.e. Control. The increment in tuber yield (kg/plot) of safedmusli was found $40.51 \%$ higher on application of vermicompost $(100 \%)-\mathrm{T}_{2}$, followed by $36.01 \%$ in FYM $(100 \%)-\mathrm{T}_{1}$.

Table 5: Effect of organic manures on tuber yield (kg/plot) of Safed musli intercropped under Pongamia pinnata based agroforestry system.

\begin{tabular}{|c|c|c|}
\hline Treatments & $\begin{array}{c}\text { Tuber } \\
\text { yield } \\
(\mathrm{kg} / \mathrm{plot})\end{array}$ & $\begin{array}{c}\text { Tuber } \\
\text { yield } \\
\text { (Q/ha) } \\
\end{array}$ \\
\hline $\mathrm{T}_{1}(\mathrm{FYM} 100 \%)$ & 4.23 & 32.51 \\
\hline $\mathrm{T}_{2}$ (Vermi-compost $\left.100 \%\right)$ & 4.37 & 33.62 \\
\hline $\mathrm{T}_{3}($ Neem cake $100 \%)$ & 3.26 & 25.08 \\
\hline $\mathrm{T}_{4}(\mathrm{FYM} 50 \%+$ Vermi-compost $50 \%$ ) & 4.03 & 31.00 \\
\hline $\mathrm{T}_{5}(\mathrm{FYM} 50 \%+$ Neem cake $50 \%)$ & 3.43 & 26.36 \\
\hline $\mathrm{T}_{6}($ Vermi-compost $50 \%+$ Neem cake $50 \%)$ & 3.48 & 26.74 \\
\hline $\mathrm{T}_{7}(\mathrm{FYM} 50 \%+$ Vermi-compost $25 \%+$ Neem cake $25 \%)$ & 3.87 & 29.79 \\
\hline $\mathrm{T}_{8}($ Control $)$ & 3.11 & 23.95 \\
\hline C.D $(P=0.05)$ & 0.191 & 1.45 \\
\hline S.Em \pm & 0.062 & 0.475 \\
\hline
\end{tabular}

Corresponding to tuber yield (kg/plot), the highest tuber yield (Q/ha) was obtained from $\mathrm{T}_{2}$ (Vermi-compost 100\%) which has recorded $33.62 \mathrm{Q} / \mathrm{ha}$ and increment of $40.37 \%$ against $23.95 \mathrm{Q} /$ ha tuber yield in $\mathrm{T}_{8}$ (Control) followed by $\mathrm{T}_{1}$ (FYM $100 \%$ ) and $\mathrm{T}_{4}$ (FYM 50\%+Vermi-compost 50\%) which has 
recorded $32.51 \mathrm{Q} / \mathrm{ha}(35.74 \%$ increment $)$ and $31.00 \mathrm{Q} / \mathrm{ha}$ (29.43\% increment) respectively. Gaikwad et al. (2011a) ${ }^{[14]}$ has reported that the application of vermicompost @ $2 \mathrm{t} / \mathrm{ha}$ along with Azotobactor showed significantly higher fasiculated root yield (4444 kg/ha) of safedmusli. These results are in line with of Chandrashekharan et al. (2000) ${ }^{[17]}$, Jayaprakash et al. (2003) ${ }^{[16]}$ and Paturde and Wankhede $(2004)^{[18]}$.

Results on chemical properties of post harvest soil as influenced by different treatments are shown in Table 6. All the eight treatments under study showed wide range of variation for soil nutrient parameters recorded, namely, Available $\mathrm{N}$ (kg/ha), available $\mathrm{P}_{2} \mathrm{O}_{5}(\mathrm{~kg} / \mathrm{ha})$ and available $\mathrm{K}_{2} \mathrm{O}(\mathrm{kg} / \mathrm{ha})$. The highest level of available $\mathrm{N}(\mathrm{kg} / \mathrm{ha})$ was recorded in $\mathrm{T}_{2}$ (Vermi-compost 100\%)i.e213.66 kg/ha ( $112.91 \%$ increment) followed by $188.16 \mathrm{~kg} / \mathrm{ha}$ in $\mathrm{T}_{4}(\mathrm{FYM}$ $50 \%+$ Vermi-compost $50 \%$ ) with $87.50 \%$ increment and $167.07 \mathrm{~kg} / \mathrm{ha}$ in the $\mathrm{T}_{6}$ (Vermi-compost $50 \%+$ Neem cake $50 \%$ ) with $66.49 \%$ increment. While minimum available $\mathrm{N}$ (kg/ha) was observed in $\mathrm{T}_{3}$ (Neem cake $100 \%$ )i.e125.44 kg/ha ( $25 \%$ increment) against $100.35 \mathrm{~kg} / \mathrm{ha}$ in $\mathrm{T}_{8}$ (Control) i.e. no manuring. Kumar et al. (2011) ${ }^{[20]}$ has also recorded $266 \mathrm{~kg} / \mathrm{ha}$ available $\mathrm{N}$ through vermicompost treatment in stevia. There have been other reports of increase of $\mathrm{N}$ in soil after application of vermicompost (Nethra et al., 1999) ${ }^{[19]}$. The highest level of available $\mathrm{P}_{2} \mathrm{O}_{5}(\mathrm{~kg} / \mathrm{ha})$ was recorded in $\mathrm{T}_{4}$ (FYM 50\%+Vermi-compost 50\%)i.e21.86 kg/ha (201.5\% increment) followed by $18.27 \mathrm{~kg} / \mathrm{ha}$ in $\mathrm{T}_{2}$ (Vermi-compost $100 \%$ ) with $152 \%$ increment and $17.11 \mathrm{~kg} / \mathrm{ha}$ in the $\mathrm{T}_{7}(\mathrm{FYM}$ $50 \%+$ Vermi-compost $25 \%+$ Neem cake $25 \%$ ) with $136 \%$ increment. While minimum available $\mathrm{P}_{2} \mathrm{O}_{5}$ (kg/ha) was observed in $\mathrm{T}_{3}$ (Neem cake $\left.100 \%\right)$ i.e $7.52 \mathrm{~kg} / \mathrm{ha}(3.72 \%$ increment) against $7.25 \mathrm{~kg} / \mathrm{ha}$ in $\mathrm{T}_{8}$ (Control) i.e. no manuring. The rest of the treatments had increased the available $\mathrm{P}_{2} \mathrm{O}_{5}(\mathrm{~kg} / \mathrm{ha})$ of post harvest soil ranging from $82.89 \%$ to $105 \%$. This result was in conformity with Kumar et al. (2011) ${ }^{[20]}$ where highest phosphorus content was achieved in T6 (76.6 kg ha-1) i.eFYM 50\%+Vermi-compost 50\%) in stevia. The highest level of available $\mathrm{K}_{2} \mathrm{O}(\mathrm{kg} / \mathrm{ha}$ )was recorded in $\mathrm{T}_{2}$ (Vermi-compost $100 \%$ ) i.e465.12 $\mathrm{kg} / \mathrm{ha}(56.60 \%$ increment) followed by $429.76 \mathrm{~kg} / \mathrm{ha}$ in $\mathrm{T}_{4}$ (FYM $50 \%+$ Vermi-compost $50 \%$ ) with $44.70 \%$ increment and $400.05 \mathrm{~kg} / \mathrm{ha}$ in the $\mathrm{T}_{7}$ (FYM $50 \%+$ Vermi-compost $25 \%+$ Neem cake $25 \%$ ) with $34.69 \%$ increment. While minimum available $\mathrm{K}_{2} \mathrm{O}(\mathrm{kg} / \mathrm{ha})$ was observed in $\mathrm{T}_{3}$ (Neem cake $100 \%)$ i.e $312.13 \mathrm{~kg} / \mathrm{ha}(5.09 \%$ increment $)$ against $297.02 \mathrm{~kg} / \mathrm{ha}$ in $\mathrm{T}_{8}$ (Control) i.e. no manuring. The rest of the treatments had increased the available $\mathrm{K}_{2} \mathrm{O}(\mathrm{kg} / \mathrm{ha})$ of post harvest soil ranging from $8.82 \%$ to $18.58 \%$. These results are in conformity with Azarmiet al. (2008) ${ }^{[22]}$ where the soil available $\mathrm{K}$ increased significantly with vermicompost application at the rate of 15,10 and $5 \mathrm{t}$ ha- 1 increased available $\mathrm{K}$ in these treatments 58, 46 and $34 \%$ respectively in comparison to control plots in tomato. Manivannan et al. (2009) ${ }^{[21]}$ has reported that an earthworm-processed waste material contains a higher concentration of exchangeable $\mathrm{K}$ due to enhanced microbial activity during the vermicomposting process, which consequently enhances the rate of mineralization. Gaikwad et al. $(2011 \mathrm{~b}){ }^{[15]}$ has reported that the application of vermicompost @ $2 \mathrm{t} / \mathrm{ha}+$ Azotobactor recorded significantly the highest available nitrogen content $(790.84 \mathrm{~kg} / \mathrm{ha})$ in soil after harvest and a significantly the lowest available nitrogen content observed $(536.73 \mathrm{~kg} / \mathrm{ha})$ under control in safedmusli.

Table 6: Effects of different treatments on nutrient status of post- harvest soil.

\begin{tabular}{|c|c|c|c|}
\hline Treatments & $\begin{array}{c}\text { Available N } \\
\text { (kg/ha) }\end{array}$ & $\begin{array}{c}\text { Available } \mathrm{P}_{2} \mathrm{O}_{5} \\
(\mathrm{~kg} / \mathrm{ha})\end{array}$ & Available $\mathrm{K}_{2} \mathrm{O}(\mathrm{kg} / \mathrm{ha})$ \\
\hline $\mathrm{T}_{1}(\mathrm{FYM} 100 \%)$ & 150.52 & 14.87 & 340.12 \\
\hline $\mathrm{T}_{2}$ (Vermi-compost $\left.100 \%\right)$ & 213.66 & 18.27 & 465.12 \\
\hline $\mathrm{T}_{3}($ Neem cake $100 \%)$ & 125.44 & 7.52 & 312.13 \\
\hline $\mathrm{T}_{4}(\mathrm{FYM} 50 \%+$ Vermi-compost $50 \%)$ & 188.16 & 21.86 & 429.76 \\
\hline $\mathrm{T}_{5}(\mathrm{FYM} 50 \%+$ Neem cake $50 \%)$ & 160.56 & 13.26 & 323.23 \\
\hline $\mathrm{T}_{6}($ Vermi-compost $50 \%+$ Neem cake $50 \%)$ & 167.07 & 14.69 & 352.21 \\
\hline $\mathrm{T}_{7}(\mathrm{FYM} 50 \%+$ Vermi-compost $25 \%+$ Neem cake $25 \%$ ) & 163.21 & 17.11 & 400.05 \\
\hline $\mathrm{T}_{8}($ Control $)$ & 100.35 & 7.25 & 297.02 \\
\hline C.D $(P=0.05)$ & 7.818 & 0.743 & 6.915 \\
\hline S.Em \pm & 2.553 & 0.243 & 2.258 \\
\hline
\end{tabular}

The three growth parameters of karanj (Pongamia pinnata) such as height $(\mathrm{m})$, diameter of breast height $(\mathrm{cm})$ and number of branch/tree were recorded before planting of safedmusli and after harvesting of safedmusli. A paired-samples t-test was conducted to check if there was significant increase by comparing the growth parameters of karanj before planting of safedmusli and after harvesting of safedmusli. The effect of intercropping on the growth of tree (Pongamia pinnata) data with respect to tree height $(\mathrm{m})$, diameter at breast height $(\mathrm{cm})$ and number of branch/tree is presented in Table 7. There was a significant difference in the scores for height $(\mathrm{m})$ before planting of safedmusli $(\mathrm{M}=6.48, \mathrm{SD}=1.41)$ and height $(\mathrm{m})$ after harvesting of safedmusli $(\mathrm{M}=6.77, \mathrm{SD}=1.48)$ conditions; $\mathrm{t}(7)=8.32^{*}, \mathrm{p}=0.005$. These results suggested that there was a significant increase in height $(\mathrm{m})$ when karanj is intercropped with safedmusli. The average tree height $(\mathrm{m})$ has increased from $6.48 \mathrm{~m}$ to $6.77 \mathrm{~m}$ during the intercropping period. There was a significant difference in the scores for diameter at breast height $(\mathrm{cm})$ before planting of safedmusli $(\mathrm{M}=18.72, \mathrm{SD}=2.63)$ and diameter at breast height $(\mathrm{cm})$ after harvesting of safedmusli $(\mathrm{M}=19.06, \mathrm{SD}=2.64)$ conditions; $t(7)=4.56^{*}, p=0.005$. These results suggested that there was a significant increase in diameter at breast height $(\mathrm{cm})$ when karanj is intercropped with safedmusli. The average tree diameter at breast height $(\mathrm{cm})$ has increased from $18.72 \mathrm{~cm}$ to $19.06 \mathrm{~m}$ during the intercropping period. There was a significant difference in the scores for number of branch/tree before planting of safedmusli $(\mathrm{M}=9.37, \mathrm{SD}=1.68)$ and number of branch/tree after harvesting of safedmusli $(\mathrm{M}=10.00$, $\mathrm{SD}=1.41$ ) conditions; $\mathrm{t}(7)=4.16^{*}, \mathrm{p}=0.005$. These results suggested that there was a significant increase in number of branch/tree when karanj is intercropped with safedmusli. The average number of branch/tree has increased from 9.37 to 10.00 during the intercropping period. Results has shown that there were only minor increase in height $(\mathrm{m})$, diameter at breast height $(\mathrm{cm})$ and number of branch/tree in karanj i.e 
$4.47 \%, 1.81 \%$ and $6.72 \%$ respectively after harvesting of safedmusli, possibly due to shorter duration of experimental period. Kaushik et al. (2016) ${ }^{[29]}$ reported increased Karanj growth (height and diameter) in Agri-silviculture as compared to sole plantation.

Table 7: Effect of intercropping on general morphological characters of Pongamia pinnata trees.

\begin{tabular}{|c|c|c|c|c|c|c|}
\hline Parameters & mean BT & mean AT & Difference & SD & Paired t & p Value \\
\hline Height $(\mathrm{m})$ & 6.48 & 6.77 & 0.29 & 0.10 & 8.32 & $<0.01$ \\
\hline DBH $(\mathrm{cm})$ & 18.72 & 19.06 & 0.34 & 0.21 & 4.56 & $<0.01$ \\
\hline No. of branch/tree & 9.37 & 10.00 & 0.63 & 0.43 & 4.16 & $<0.01$ \\
\hline
\end{tabular}

\section{Conclusion}

It is revealed that there was great variation among the different organic manure treatments for yield parameters of safedmusli and soil chemical properties. Beneficial effect of intercropping on karanj trees was also observed. Vermicompost (100\%) performed outstanding for improvement of tuber length $(11.85 \mathrm{~cm})$, number of tubers (8.57 no.), number of leaves/plant $(27.89,90 \mathrm{DAP})$ and tuber yield (4.37 kg/plot).High performance of vermicompost could be due to very rich and diverse microbial populations present in vermicompost. The soil chemical properties on post harvest soils was also observed with higher concentrations of $\mathrm{N}$ $(213.66 \mathrm{~kg} / \mathrm{ha})$ and $\mathrm{K}_{2} \mathrm{O}(465.12 \mathrm{~kg} / \mathrm{ha})$ in vermicompost $(100 \%)$ treated plot. It may be due to the process of mineralization and availability of nutrients as enhance by vermicompost that resulted in better performance in crop and post harvest nutrient status. This experiment also revealed that safedmusli can be successfully grown in karanj based agroforestry system with mutual benefit.

\section{References}

1. Khanam Z, Singh O, Singh R, Bhat IUH. Safed musli(Chlorophytum borivilianum): A review of its botany, ethnopharmacology and phytochemistry. Journal of Ethnopharmacology 2013;150(2):421-441.

2. Oudhia P. Problems perceived by safedmoosli (Chlorophytum borivilianum) growers of Chhattisgarh (India) region: a study. Problems perceived by safedmoosli (Chlorophytum borivilianum) growers of Chhattisgarh (India) region: a study 2000;22(4a):396399.

3. Kothari SK, Singh K. Evaluation of safedmusH (Chlorophytum borivilianumSantapau\& Fernandes) germplasm. Journal of Spices and Aromatic Crops 2001;10(2), 147-149.

4. Suvera AH, Thakur NS, Jha SK. Herbage and essential oil yield of Ocimum spp. Intercropped under Pongamia pinnata based silvi-medicinal systems in Gujarat, India. The Bioscan 2015;10(1):81-85.

5. Duke JA. Handbook of Energy Crops. Nitrogen fixing trees, In: The International Perma Culture Seed Yearbook. Orange, MA 1983, pp. 48-51.

6. Beniwal RS, Chauhan R. Pongamia pinnata as an alternative source of renewable energy. Asia-Pacific AgroforestryNewsletter 2011;38:14-15.

7. Kumari A, Kumar R, Maurya S, Choudhary JS, Kumar S. Antifungal efficacy of aqueous extracts of neem cake, karanjcake and vermicompost against some phytopathogenic fungi. The Bioscan 2013;8(2):671-674.

8. Dhingani JC, Solanky KU, Kansara SS. Managementof root rot disease [Macrophominaphaseolina (Tassi.)Goid] ofchickpea through botanicals and oil cakes. The Bioscan 2013;8(3):739-742.

9. Sarma AK, Konwer D, Bordoloi PK. A comprehensive analysis of fuel properties of biodiesel from Koroch seed oil. Energy Fuels 2005;19:656-7.

10. Meera B, Kumar S, Kalidhar SB. A review of the chemistry and biological activity of Pongamia pinnata. Journal of Medicinal and Aromatic Plant Science 2003;25:441-65.

11. Panse VG, Sukhatme PV. Statistical Methods for Agricultural Workers. 2nd Ed. Indian Council of Agricultural Research, New Delhi 1967, 381.

12. Kothari S, Singh K. Production techniques for the cultivation of safedmusli (Chlorophytum borivilianum). The Journal of Horticultural Science and Biotechnology 2003;78(2):261-264.

13. Patel DH, Upadhyay NV, Patel MA, Macwan SJ, Sriram S. Effect of organic manures and spacings on fasciculated root yield of safedmusli (Chlorophytum borivilianum). Indian Journal of Agricultural Research 2008;42(1):3136.

14. Gaikwad VP, Bhosale ND, Patel DH, Patel RB, Chaudhari NJ. Growth and yield of safedmusli (Chlorophytum borivillianum, Santapau and Fernandes) as influenced by bulky and concentrated organic manures grown under loamy sand soil. Advance Research Journal of Crop Improvement 2011a;2(1), 135-137.

15. Gaikwad VP, Patel RB, Bhosale ND, Shinde VT, Patel DH. Effect of organic manures and biofertilizer on soil fertility, yield and quality of safedmusli (Chlorophytum borivilianum, Sant. and Fern.). Asian Journal of Soil Science 2011b;6(2):111-113.

16. Jayprakash TC, Nagalikar VP, Shetty RA. Effects of organic and inorganic manures on yield and yield attributes of maize. Karnataka J. Agric. Sci 2003;16(3):586- 592.

17. Chandrashekaran CP, Harlapur SI, Girish GK. Response of maize to organic manures with inorganic fertilizers. Karnataka J Agric. Sci 2000;13(1):144-146.

18. Paturde JT, Wankhede SG. Effect of organic manures and fertilizers on yield and quality of Safed musli. PKV Res. J 2004;20(1):45-47.

19. Nethra NN, Jayaprasad KV, Kale RD. China aster (Callistephus chinensis L.) cultivation using vermicomposts as organic amendment, Crop Res. Hisar 1999;17(2):209-215.

20. Kumar MC, Gaval AR, Rathod P, Chandregowda M. Effect of organic manures and bio-fertilizers on soil chemical properties and plant nutrient uptake in Stevia (Stevia rebaudiana). Journal of Ecobiology 2011;29(3):181.

21. Manivannan S, Balamurugan $M$, Parthasarathi $K$, Gunasekaran G, Ranganat LS, et al. Effect of vermicompost on soil fertility and crop productivity beans (Phaseolus vulgaris). J Env. Bio 2009;30(2):275281.

22. Azarmi R, Giglou MT, Taleshmikail RD. Influence of vermicompost on soil chemical and physical properties in tomato (Lycopersicum esculentum) field. African Journal of Biotechnology 2008;7(14).

23. Chauhan HS, Aparbal S, Singh HP, Singh AK, Chattopadhyay A, Raj Kumari PA, et al. Influence of FYM and NPK fertilizers on growth and yield of safedmusli (Chlorophytum borivilianum) production. J. Med. Aromat. Plant Sci 2005;22(1B):447-449. 
24. Kulmi GS, Tyagi SK. Response of safedmusli (Chloropyhtumborivilianum Santapau \& Fernandes) varieties to organic nutrition in vertisols of Malwa Plateau of Madhya Pradesh. Journal of Medicinal and Aromatic Plant Sciences 2010;32(1):58-60.

25. Emura K, Hosoya T. Effect of fertilization on the quality and yield of spring sowed carrots. Bulletin of the Saitawa Horticultural Experimental Station 1979, pp. 13-23.

26. Shravankumar CS, Soumana D. Impact of organic manure ammendment on Withaniasomnifera (L.) Dunal var JA-134. Bulletin of Environment, Pharmacology and Life Sciences, Bull. Env. Pharmacol. Life Sci 2016;5:1116.

27. Alam MN, Jhan MS, Ali MK. Effect of vermicompost and chemical fertilizers on growth, yield and yield attributes of Potato. J Appl. Sci. Res 2007;3(12):18791889.

28. Bong KK, Naher VP. Effect of vermicompost on growth of fall- cropping potato in volcanic ash soil. Korean J. Crop Sci 2004;49(4):305-308.

29. Kaushik N, Deswal RPS, Tikkoo A, Kumari S, Malik S, Kumar K, et al. Pongamia pinnataL.(Karanja) based agri-silviculture system under rainfed conditions of south-west Haryana. Journal of Applied and Natural Science 2016;8(1):31-34. 